\title{
The development of parental monitoring during adolescence : A meta-analysis
}

\section{Lionetti, Francesca}

2019-09-03

Lionetti , F, Palladino , B E , Passini , C M , Casonato , M , Hamzallari , O , Ranta , M , Dellagiulia , A \& Keijsers , L 2019 , ' The development of parental monitoring during adolescence : A meta-analysis ' , European Journal of Developmental Psychology , vol. 16 , no. 5 , pp. 552-580 . https://doi.org/10.1080/17405629.2018.1476233

http://hdl.handle.net/10138/311390

https://doi.org/10.1080/17405629.2018.1476233

acceptedVersion

Downloaded from Helda, University of Helsinki institutional repository.

This is an electronic reprint of the original article.

This reprint may differ from the original in pagination and typographic detail.

Please cite the original version. 


\section{The development of parental monitoring during adolescence:}

\section{A meta-analysis}

Francesca Lionetti ${ }^{1}$, Benedetta Emanuela Palladino ${ }^{2}$, Christina Passini $^{3}$, Marta Casonato ${ }^{4}$, Oriola Hamzallari ${ }^{5}$, Mette Ranta ${ }^{6}$, Antonio Dellagiulia ${ }^{7}$, Loes Keijsers ${ }^{8}$

${ }^{1}$ Queen Mary University of London, UK

${ }^{2}$ University of Florence, IT

${ }^{3}$ University of Geneva, FR

${ }^{4}$ University of Turin, IT

${ }^{5}$ Aleksander Moisiu University, AL

${ }^{6}$ University of Helsinki, Helsinki, FI

${ }^{7}$ Salesian University of Rome, IT

${ }^{8}$ Tilburg University, NL

Citation: Lionetti, F., Palladino, E. B., Passini Moses, C., Casonato, M., Hamzallari, O., Ranta, M., Dellagiulia, A., Keijsers, L. (in press). The development of parental monitoring during adolescence: A meta-analysis. European Journal of Developmental Psychology

\section{Acknowledgment}

The authors would like to thank the Early Researchers Union of the European Association for Developmental Psychology, the European Association for Developmental Psychology and Jacobs Foundation for supporting the writing week held in April 2015 at Transylvania University of Brasov, where the current paper was initially drafted.

This study was partially supported by a research grant from the Netherlands Organization for Scientific Research (NWO VIDI: 452-17-011) awarded to Loes Keijsers 


\title{
The development of parental monitoring during adolescence:
}

\section{A meta-analysis}

\begin{abstract}
As adolescents grow up, one of the important developmental tasks is to individuate themselves and to become more autonomous from parents. This requires a realignment of the parent-adolescent communication. The current meta-analytic study aims at identifying developmental changes in parent-adolescent communication, conceptualized within the parental monitoring framework, as entailing parental solicitation, control and knowledge, and adolescent's disclosure and secrecy. Thirty-one longitudinal studies published between 2000 and 2015 were identified and included in the current meta-analysis. Informants, age at assessment and study duration were tested as moderators. Results showed a low to medium normative decline in parental control (Cohen's $d=-.395,95 \% \mathrm{Cl}[-.541,-.249]$ ), knowledge ( $\mathrm{d}$ $=-.245,95 \% \mathrm{Cl}[-.331,-.160]$ and adolescence disclosure $(\mathrm{d}=-.147,95 \% \mathrm{Cl}[-.204,-.090])$, and an increase in adolescent's secrecy $(\mathrm{d}=.194, \mathrm{Cl}[031, .356])$. Parental solicitation decreased based on parents' $(\mathrm{d}=-0.242,95 \% \mathrm{Cl}[-0.376,-0.109])$ but not on adolescents' reports $(\mathrm{d}=$ $0.038,95 \% \mathrm{Cl}[-0.099,0.175])$. Another significant moderator was the duration of the study, with studies longer than 2 years being able to detect a more pronounced change in parental control than studies lasting less than 2 years ( $\leq 2$ years, $d=-0.139$ vs. duration $>2$ years, $d=-$ 0.581). Limitations of the current knowledge and new direction of studies are discussed.
\end{abstract}

Key-words: Parental solicitation, parental control, parental knowledge, adolescent disclosure, adolescent secrecy, parental monitoring 
When children mature, and enter high school, much of their daily lives take place outside the direct supervision of their parents. During this developmental phase, monitoring adolescents' activities allows parents to stay involved in their lives, without a need to be physically present. Parental monitoring, described as a set of parenting behaviors aimed at paying attention to and tracking of the adolescent's whereabouts, activities, adaptations, and friendships (Dishion \& M cM ahon, 1998), has long been considered as one of the most important protective factors against adolescent problem behaviors. For instance, already in the 50's it was described that parents of antisocial children scored relatively low in tracking how their children spend their free time out of school (Glueck \& Glueck, 1950); similarly, subsequent quantitative studies reported protective effects of parental monitoring against adolescents' delinquency and drug use (Patterson $\&$ StouthamerLoeber, 1984; Stouthamer-Loeber \& Loeber, 1986). As such, adequate parental monitoring during adolescence became a key-element in theories on the development of adolescent delinquency (Gottfredson \& Hirschi, 1990; Patterson \& Dishion, 1985).

At the threshold of the new millennium, these conceptual formulations were challenged by the empirical studies of Stattin and Kerr (Kerr \& Stattin, 2000; Stattin \& Kerr, 2000). Thanks to their seminal contribution, the focus of research on monitoring switched from parental monitoring behaviors only, to the inclusion of adolescents' behavior as well, and from measuring parental knowledge to including measures of the process through which parents come to know about their children (i.e. the willingness of children themselves to disclose to their parents vs. gaining information from soliciting or controlling information by parents). Specifically, the focus and thinking about parental monitoring in developmental and clinical studies gradually shifted from an unidirectional active role of parents in promoting well-being towards a more transactional and dynamic view where adolescent's agency is a core component of the monitoring process (Keijsers, 2016; M eeus, 2016; Racz \& M cM ahon, 2011; Smetana, 2008).

In line with the assumption that parental knowledge is the product of a bidirectional process taking place in the parent-adolescent dyad, there has been increased attention to realignment of 
communication (Branje, Finkenauer, \& M eeus, 2008; Branje, Laursen, \& Collins, 2013; Smetana, 2008). Specifically, it has been suggested that developmental changes in communication allows adolescents to progress towards an increased autonomy and independence, while remaining connected to their parents (Keijsers \& Poulin, 2013; Van der Giessen et al., 2014). The main aim of the current meta-analytic study is to contribute to the empirical identification of developmental changes in parent-child communication within the parental monitoring theoretical framework and, more specifically, to explore developmental changes in relation to parental control, solicitation and knowledge, and adolescence disclosure and secrecy (Kerr \& Stattin, 2000; Stattin \& Kerr, 2000). To describe how communication varies across ages in relation to these key-variables is the main aim of the current meta-analysis. Reviewing the literature in the parental monitoring framework, we also highlight limitations of the current knowledge, suggesting new directions of studies.

\section{Parental monitoring: A conceptual definition}

Over the last decades, it has become evident that the literature on parental monitoring needed to be conceptually refined, and several suggestions have been made how to better conceptualize the parenting behaviors involved and to operationalize the measurements. In fact, there is now a rather wide variety of parenting practices described in the literature that would fit under the umbrella term of parental monitoring (Dishion \& M cM ahon, 1998). Parents can solicit information by asking their child to reveal the information (Stattin \& Kerr, 2000) or rely on information they receive from knowledgeable others, such as neighbors or teachers (Waizenhofer, Buchanan, \& Jackson-Newsom, 2004). Parents may also control their children, demanding that they inform them about their leisure time activities, friendships, and whereabouts (labeled parental control, Stattin \& Kerr, 2000). Moreover, parents can try to influence the actual whereabouts, activities, adaptations, and friendships, for instance by contributing to structuring their children's leisure time activities (Fletcher, Steinberg, \& Williams-Wheeler, 2004). In our meta-analysis we will report data on the two strategies that are mostly widely studied and were introduced by Stattin \& Kerr (2000) - parental 
solicitation and control, and to the final product to which these parenting practices contribute to, that is parental knowledge of out of home activities.

As carefully introduced by the work of Stattin and Kerr (2000), adolescents themselves also play an active role in managing the information their parents receive. That is, adolescent's disclosure regarding leisure time was identified as a strong predictor of how much parents know (Keijsers, Branje, Frijns, Finkenauer, \& M eeus, 2010; Stattin \& Kerr, 2000). Building further on this work, it became evident that distinguishing between disclosure and secrecy would potentially allow to add to our understanding of monitoring. Including secrecy in some studies, for instance, has helped to obtain a more in depth understanding of differences between parent-adolescent and peer-to-peer communication (Solís, Smetana, \& Comer, 2015), and has indicated that adolescents' secrecy is a strong predictor of parental knowledge (Tilton-Weaver, 2014) and adolescents' delinquency and norm breaking (Keijsers, 2016). Moreover, also psychometrically, disclosure and secrecy are related, yet separate, factors (Lionetti, Keijsers, Dellagiulia, \& Pastore, 2016). Therefore, both adolescent secrecy and disclosure will be examined in this meta-analysis.

\section{Parental monitoring: A developmental perspective}

Adolescence is a period of pronounced changes in the physical, social, and emotional domain (Lerner $\&$ Steinberg, 2009), and with these changes also patterns of communications are expected to change. Quite frequently, parents struggle with the questions regarding the normative patterns, such as what are age-appropriate levels of parental control, and is it age-normative for adolescents and young adults to keep secrets? Though each parent-child relationship is unique, and multiple variables (e.g. parenting style, personality traits) are likely to contribute to parent-child communication development, to investigate normative patterns of change within the parental monitoring framework may provide more information on how, and to what extent, on average the parent-child communication changes across years. 
Over the course of adolescence, the parent-child relationship has to be realigned in order to adjust to the increasing privacy and autonomy needs of adolescents (Collins, 1990; Collins \& Laursen, 2004; Petronio, 2002). These developmental forces not only affect the hierarchical distribution of power in the relationships, but also likely affect the monitoring and communication processes within families (Branje et al., 2013; Smetana \& Asquith, 1994). Due to adolescents' increasing tendencies to spend time outside the parents' home (Larson \& Richards, 1991), parents can decreasingly rely on direct supervision (Dishion \& M cM ahon, 1998), and need to rely on adolescent's disclosure as a source of knowledge (Stattin \& Kerr, 2000). However, compared to children, adolescents may be more tempted to keep secrets from their parents as a result of an increased need of privacy (Petronio, 2002). Similarly, adolescents may share less with their parents to preserve their autonomy and achieve a greater differentiation (Branje, Laursen, $\&$ Collins, 2012). Furthermore, the legitimacy of parents' attempts to control the lives of adolescents may decrease (Smetana, 1989; Smetana \& Asquith, 1994). As such, we expected to find that parental monitoring efforts and adolescent willingness to share information both decline over the course of adolescence; resulting in a decrease in parental knowledge. Although some longitudinal studies have tested these changes (Keijsers \& Poulin, 2013; Masche, 2010), a meta-analysis of the empirical findings from longitudinal studies regarding these changes is currently lacking.

\section{What moderates parent-child communication?}

Apart from studying normative (or average) developmental changes, we were also interested in examining heterogeneity, thereby focusing on two theoretical predictors, gender and country of origin, and on three important elements of the study design, which are informant, age at assessment, and duration of the longitudinal study. However, due to the limited number of longitudinal studies conducted in non-Western Countries, and to the limited number of studies reporting information on gender differences (see Table 1), we introduce gender and country of 
origin as moderators only at a descriptive level and we statistically test as moderators informant, age at assessment and duration of the study.

Theoretical predictors. Though only a few studies reported relevant information for testing the role of gender at a meta-analytic level, there are strong evidences suggesting that the normative changes in parent-adolescent communication may very well vary between boys and girls. Empirical studies showed that girls often report more parental knowledge, adolescent's disclosure, parental solicitation and parental control than boys do (Crouter \& Head, 2002; Hamza \& Willoughby, 2011; Kerr \& Stattin, 2000; Stattin \& Kerr, 2000), yet whether this also results in distinct developmental changes is unclear, as heterogeneity between empirical result may occur. For instance, even though one study found that the increase of secrecy throughout adolescence was faster for boys than for girls (Keijsers et al., 2010), another study found stable levels of secrecy for boys over the course of adolescence at a within level of analysis (Keijsers \& Poulin, 2013).

Because norms and expectations in terms of parent-adolescent communication rules and habits could vary across cultures, the moderating role of the country of origin should be considered. For example, the parent-child relationship quality and degree of communication may be different in Asian cultures, where the family is considered central (Son \& Choi, 2013), compared to Western countries. As such, it may be that parental control is not necessarily related to violation of children's sense of self as it might be in a European-American setting (Wang, Pomerantz, \& Chen, 2007). At the same time, some of the underlying processes may overlap. For instance, in a study involving Chinese and American adolescents (Qin \& Pomerantz, 2013), the relation between youth's sense of responsibility and disclosure to parents were found in both cultures, despite cultural differences in the levels of independence from parents have been reported in the literature, with American adolescents more strongly marked by need of establishing independence from parents (Collins \& Steinberg, 2006) compared to Chinese adolescents (Pomerantz, Qin, Wang, \& Chen, 2011). M oreover, comparing the same cultural backgrounds, in another study (Wang et al., 2007) parental control predicted adolescents' enhanced academic functioning regardless of the cultural context. 
Methodological predictors. The psychological assessment of children and parents, when it comes to adolescence, often involves the employment of multiple informants; however, informants often disagree. For example, reports of behavioral problems, psychiatric symptoms and even of benefits after intervention programs have been found to significantly diverge between parents and children (Achenbach, 2006; Weisz, M cCarty, \& Valeri, 2006; Yungstrom, Findling, \& Calabrese, 2003; De Los Reyes, Goodman, Kliewer, \& Reid-Quinones, 2008). Whenever parent-child communication is studied, the eye of the beholder, i.e. the informant, may be a crucial factor too. Interestingly, previous studies have shown low levels of agreement between parents and children's report of parental monitoring (De Los Reyes, Goodman, Kliewer, \& Reid-Quinones, 2010; Keijsers et al., 2010). When different reports about the same behavior differ depending on the informant, it could be difficult for policy-makers and researchers to interpret research findings, for example, to understand what causes that behavior, what are its consequences and how it develops over time (De Los Reyes, Henry, Tolan, \& Wakschlag, 2009; De Los Reyes \& Kazdin, 2009; Han et al., 2012; Pasch, Stigler, Perry, \& Komro, 2010). Although there is no conclusive way for determining the best informant, by acknowledging differences among informants, results among studies could be compared and results interpreted taking into account differences among individuals.

The study designs also vary in terms of the time window under examination, which is the duration of the study. The age of the first assessment in studies assessing monitoring longitudinally, for instance, ranges from middle-childhood (Glatz, Stattin, \& Kerr, 2011; Keijsers, Loeber, Branje, \& Meeus, 2012) to late adolescence (Keijsers, Branje, et al., 2012; Van der Giessen et al., 2014). M oreover, whereas some studies only last 6 months (Stavrinides, Nikiforou, \& Georgiou, 2015) others follow children up to 7 years (Keijsers \& Poulin, 2013). We have therefore examined whether developmental changes are more likely to take place at specific ages or as a result of the duration of the study.

\section{The current study}


The current study aimed at identifying normative trends in parental monitoring considering all studies published between 2000 to 2015 in which the scales proposed by Stattin and Kerr (2000), named parental control, solicitation and knowledge, and adolescent's disclosure have been used. Moreover, following more recent insights in the psychometric properties of the disclosure scale (e.g., Frijns et al, 2010; Lionetti et al, 2016), we also included studies that computed adolescent secrecy, based on a subset of items from the disclosure scale. First, we aimed at providing information on average changes in parental control, solicitation and knowledge, and adolescent's disclosure and adolescent secrecy, to obtain information on age-normative development during adolescence. In doing this, we have focused exclusively on longitudinal studies to avoid confusion between cohort and age effects. Second, we examined two theoretical (i.e., gender and country of origin) and three methodological moderators (i.e., informant, age at assessment and duration of the study).

\section{Method}

In order to conduct a structured review, we followed the PRISM A guidelines for systematic reviews and meta-analyses (M oher, Liberati, Tetzlaff, Altman, \& Group, 2009) as summarized in the flowchart reported in Figure 1.

\section{Identification}

We identified potential relevant articles by searching in the SCOPUS, Web of Science and PsychInfo scientific databases. The search was conducted in 2015 , April $21^{\text {st }}$. First, we set the following inclusion criteria: (1) the articles should cite Stattin and Kerr (2000) and/or Kerr and Stattin (2000) papers as an indication that the relevant scales were assessed, and (2) they should contain in either the title, abstract, or keywords at least one of the following keywords: disclos*; information manag*; manag* of information; secre* or conceal*; parent* monitor* or parent* knowledge or parent* monitor* knowledge; parent* solicitat* or parent* control* or parent* monitor* rule*or parent* rule*. Citing

Stattin and Kerr (2000), 347 papers in Psycinfo, 344 in Web of Science, and 329 in Scopus were 
identified, whereas citing Kerr and Stattin (2000) we found 251 papers in Psychlnfo, 291 in Web of Science, and 308 in Scopus.

As a second identification step, we delimited the selection of papers to (1) empirical research articles (in Scopus and Web of Science, we included "article" as a criterion, in Psyclnfo we selected only "peer-reviewed journals"), and (2) articles written in English. Citing Stattin and Kerr (2000), 322 papers were identified in PsychInfo, 323 in Web of Science, and 316 in Scopus, whereas citing Kerr and Stattin (2000) we identified 157 papers in PsychInfo, 270 in Web of Science, and 263 in Scopus.

Finally, we selected the ten journals in which authors had most often cited the articles of Stattin and Kerr (2000) and Kerr \& Stattin (2000). We manually screened the online platform of these journals for identifying online papers that potentially could have met our search criteria but that were not yet included in the scientific databases. No additional articles were identified.

At the end of the identification phase, 1651 records were identified through these database searches. Screening and evaluation of the eligibility of papers are summarized in Figure 1.

\section{\#\#\#\#IGURE 1 AROUND HERE}

\section{Screening}

All records were imported into Endnote Web. The duplicates were removed, first automatically leading to 882 articles - and then manually- leading to 468 ones. The selection phase based on reading the title, keywords and abstract was done in accordance with the following hierarchical criteria: (1) longitudinal studies (i.e., two or more repeated assessments); (2) adolescent sample (i.e., age range of participants ranging from 12 to 25 at the first wave of data collection); (3) community samples (e.g., adolescents with special needs, such as HIV or diabetes were excluded); and (4) empirical research article. The screening was done twice and in parallel by the golden standard rater, Associate Professor and expert in the parental monitoring field (LK), and by a group of young scholars (i.e. doctoral or postdoc level, FL, BEP, MC, OK, M R, AD). The inter-rater agreement between the golden standard rater 
and the group, computed on the acceptance/rejection criterion, was acceptable (Cohen's $K=0.86$ [0.81 - 0.91]). Two post-doctoral researchers (FL and BEP) and the golden rater (LK) recoded again independently all the articles for which an agreement was not reached during the first screening phase. The inter-rater agreement at this point was 100\%. This resulted in 196 records selected for the eligibility phase.

\section{Eligibility}

The full-text versions of these 196 articles were downloaded and again rated independently both by the golden standard rater and the group of young scholars. Entire papers were screened on the bases of the following three hierarchical criteria: (1) measures directly derived from Stattin and Kerr (2000); (2) dataset based on community samples and sample age range between 12 to 25 years old; (3) Iongitudinal data collection of the measures of interest. The inter-rater agreement was again high (Cohen's K =.94 [0.89 - 0.99]). Disagreements were discussed to reach a 100\% agreement; 33 articles remained after this phase and are all reported in Table 1. Authors have been contacted up to three times to ask for missing information if the paper did not report values necessary for estimating developmental changes. All contacted authors but two provided data requested. Overall, 31 papers were eligible after this phase. Because some studies were (partially) based on the same longitudinal dataset, we included the studies based on the largest sample size and time span, and those which provided the more detailed information for estimating mean effect size and moderation effects in our meta-analysis (in Table 1 these articles are marked with an asterisk).

\section{\#\#\#ABLE 1 AROUND HERE}

\section{Coding}

All eligible studies were coded following these criteria: availability of data for subgroups (i.e. gender, country), informant (i.e. parents or adolescents), adolescent's age at the first assessment ( $<14$ years, 
$\geq 14$ years), and duration of the study (i.e., time elapsed between the first and the last wave of data collection; $<2$ years, $\geq 2$ years). The variables country and gender were initially coded but then not taken into account for the subsequent moderation analyses due to the insufficient variability (country) and to the limited information available from published studies (gender).

In the 31 papers considered for the analyses (Table 1), adolescent's mean age at the first assessment ranged from 11 (Glatz et al., 2011) to 16 years old (Van der Giessen et al., 2014). Because the duration of the study ranged between 0.25 and 7 years (see Table 1 ) the actual age range of adolescents in this study ranged from 11 to 20 years. All studies feature Western samples, with the exception of a contribution including Chinese adolescents (Cheung, Pomerantz, \& Dong, 2013).

\section{Strategy of analysis}

To summarize the developmental change in parent-adolescent communication (i.e., parental knowledge, parental solicitation, parental control, adolescent's disclosure, and adolescent secrecy) over these 31 studies, we used meta-analysis. The effect size metric was standardized differences in means (Cohen's $d)^{1}$ based on means, and standard deviations of the first and last wave of data collected, as well as the estimates of the correlation between these measurement waves. For each effect size estimate we computed the $95 \%$ confidence interval $(\mathrm{Cl})$. We used the Comprehensive M etaAnalysis (CM A, version 2.2) program for this purpose (Borenstein, Rothstein, \& Cohen, 2005). In order to respect the independency assumption across studies, in each study effect sizes from different informants (i.e. parent and adolescent) were combined in a single effect size when the informant variable was not tested as moderator.

In terms of the analytical model, we used the random effects model, which gives the same results as a fixed-model when applied to homogeneous studies, but has additional strengths (Borenstein, Hedges, \& Higgins Rothstein, 2009). Specifically, the random effects model assumes that the different studies estimate somewhat different values of the population parameter, thus allowing

${ }^{1} d=$ pre - posttest $\div\left(S_{\text {diff }} \div \sqrt{2}(1-r)\right)$ 
for greater generalizability to other studies not included in this meta-analysis. When outliers (effects which differed substantially from the other) were detected in the effect sizes distribution, a sensitivity analysis was conducted which consisted of omitting the outlier to check whether the results differed substantially (Borenstein et al., 2009).

We tested the distribution of the effect sizes with a homogeneity statistic, Cochran's Q. When this statistic is significant, it indicates that the dispersion of the effect sizes is unlikely to be due to sampling error. We conducted moderation analyses to account for the variability across studies, by including informant (parents vs. adolescents), age at first assessment ( $<14$ years, $\geq 14$ years), and duration of the study ( $<2$ years, $\geq 2$ years) in the model. The limited variability did not allow to statistically test the role of country. Similarly, because only a few studies reported the association between the variables of interest and gender, it was not possible to test whether gender influenced the mean level change. Categorical moderator analysis is akin to the analysis of variance (ANOVA), with a within group variance, Qw, and a between groups variance, Qb. A significant $\mathrm{Qw}$ indicates that there is a heterogeneity within that group, while a significant Qb indicates that the effect sizes between compared groups are different (cfr Borenstein, Hedges, \& Higgins Rothstein, 2009).

To account for publication bias, we calculated the fail-safe N (Rosenthal, 1979), which is the minimum number of studies with null results needed to reduce the meta-analysis results to nonsignificance.

\section{Results}

\section{Parental control}

Seventeen longitudinal studies examined developmental changes in parental control, which resulted in effect sizes $d$ ranging from -1.787 to .342 (Figure 2). Summarizing these effect sizes, there was a small to medium decrease over time $(\mathrm{d}=-.395,95 \% \mathrm{Cl}[541,-.249])$ (17 studies, total $\mathrm{N}=12,897)$. The fail-safe N was 5823, which exceeds Rosenthal (1979) threshold level of five times the number of studies in the meta-analysis plus 10. We conducted a sensitivity analysis which consisted of 
excluding outlier effect sizes of two studies, which incidentally had the longest duration (Keijsers \& Poulin, 2013; Van der Giessen et al., 2014). When the two outlier studies were removed, the decrease in parental control remained statistically significant though the effect size was reduced ( $d=$ $-.249,95 \% \mathrm{Cl}[-.387,-.111], 15$ studies, total $n=12,485)$.

The homogeneity test indicated significant heterogeneity across the set of effect sizes ( $Q$ (16) $=1040.079, p<.001)$. Subsequent moderation analyses revealed that the decrease reported by adolescents and parents was comparable in effect size $(d=-0.414,95 \% \mathrm{Cl}[0.604,-0.225], 11$ studies, total $n=8,808$ and $d=-0.365,95 \% C l,-0.568,-0.163,10$ studies, total $n=3,384$, respectively; $Q$ ( 1 ) $=0.120, p=730$ ). Moreover, the decline was found independent of the age of the adolescent at the first assessment: 14 years old or younger ( $d=-.495,95 \% \mathrm{CI}[-.721,-.270]$ ) (8 studies, total $n=6172$, vs older than $14(\mathrm{~d}=-.308,95 \% \mathrm{Cl}[-.524,-.091], 9$ studies, total $n=6425), \mathrm{Q}(1)=1.379, \mathrm{p}=.240)$. Results remained stable when the two outliers were removed. However, studies with longer duration were able to detect stronger developmental declines in parental control ( $\leq 2$ years, $d=-$ $0.139,95 \% \mathrm{Cl}:-.374, .096)(7$ studies, total $\mathrm{n}=3993)$ versus duration $>2$ years $(\mathrm{d}=-0.581,95 \% \mathrm{Cl}$ : $.779,-.382)$ (10 studies, total $n=8199), Q(1)=7.890, p=.005)$.

\#\#\#IGURE 2 AROUND HERE

\section{Parental solicitation}

Thirteen studies were identified that longitudinally assessed parental solicitation, indicating different developmental changes ( $d=-0.440$ to 0.089 ) (Figure 3 ). Summarizing the results, there was a small decrease over time $(\mathrm{d}=-0.082,95 \% \mathrm{Cl}[-.163,-.000])$ (13 studies, total $\mathrm{N}=6659)$. However, the failsafe $\mathrm{N}$ is 57 ; and therefore, this finding fails to reach the Rosenthal (1979) of fail-safe $N>5 k+10$.

The homogeneity test indicated significant heterogeneity between studies ( $Q(12)=131.251$, $\mathrm{p}<.001)$. Whereas parents reported a decrease in solicitation $(\mathrm{d}=-0.242,95 \% \mathrm{Cl}[-0.376,-0.109], 9$ studies, $n=2836)$, adolescents did not ( $d=0.038,95 \% \mathrm{Cl}[-0.099,0.175]$, 8 studies, total $n=3523)$, a 
difference that was statistically significant $(Q(1)=8.223, p=.004)$. The decrease was not moderated by age at assessment (respectively $d=-0.062,95 \% \mathrm{Cl}[-0.158,0.034], 9$ studies, $n=5801$ for adolescents 14 years old or younger, and $d=-0.134,95 \% \mathrm{Cl}[-.289,0.020], 4$ studies, $\mathrm{n}=858$ for older ones; $Q(1)=.612, p=.434$ ), nor by the duration of the study (respectively $d=-0.099,95 \% \mathrm{Cl}$ [$0.210,0.012], 8$ studies, $\mathrm{n}=2175$ for a time interval $\leq 2$ years, and $\mathrm{d}=-0.059,95 \% \mathrm{Cl}[-.191,0.073], 5$ studies, $\mathrm{n}=4484$ for a time interval $>2$ years; $\mathrm{Q}(1)=.208, \mathrm{p}=.648)$.

\#\#\#FIGURE 3 AROUND HERE

\section{Parental knowledge}

Nine studies examined developmental changes in parental knowledge, and these revealed different effect sizes ranging from $d=-.714$ to $d=.190$ (Figure 4). Overall, knowledge decreased significantly over time $(\mathrm{d}=-.245,95 \% \mathrm{Cl}[-.331,-.160], 9$ studies, total $\mathrm{N}=5510)$. The fail-safe $\mathrm{N}$ is 807 ; this exceeds Rosenthal (1979) threshold level of five times the number of studies in the meta-analysis plus 10.

There was significant heterogeneity in these effect sizes $(Q(8)=87.045, p<.001)$. In subsequent moderation analyses, only the role of informants could be tested with at least four studies per group (Fu et al., 2011). Whether the adolescent $(d=-0.259,95 \% \mathrm{Cl}[-0.383,-0.134], 6$ studies, total $n=2078)$ or parents reported on knowledge $(d=-0.303,95 \% \mathrm{Cl}[0.425,-0.182], 6$ studies, total $n=3113$ respectively), results were not statistically different $(Q(1)=0.257, p=.612$ ). Hence, other moderators, that have yet to be identified, are most likely responsible of such variability.

\#\#\#FIGURE 4 AROUND HERE

\section{Adolescent Disclosure}


The distribution of effect sizes of developmental change of disclosure ranged from -0.569 to 0.009 (negative values indicating declines; Figure 5). Over the studies, a small decrease was found ( $d=$ $.147,95 \% \mathrm{Cl}[-.204,-.090], 15$ studies, total $\mathrm{N}=9707)$. The fail-safe number, which is the minimum number of additional studies with null results, needed to overturn this significant result, is 670 . With 15 studies included in this meta-analysis, this exceeds Rosenthal (1979) threshold of 85 (i.e., five times the number of studies in the meta-analysis plus 10: fail-safe $N>5 k+10$ ).

The homogeneity test indicated that there was statistically significant heterogeneity across the set of effect sizes: $Q(14)=107.984, p<.001$, indicating a need to test for potential moderators. Comparing adolescent $(d=-0.152,95 \% \mathrm{Cl}[-0.229,-0.076], 12$ studies, total $n=7097)$ vs the parents report on adolescent's disclosure $(d=-0.173,95 \% \mathrm{Cl}[-0.270,-0.076], 7$ studies, total $n=2310)$ did not explain the heterogeneity $(\mathrm{Q}(1)=0.113, \mathrm{p}=.737)$. Neither did comparing adolescent first assessment at $\leq 14$ years $(d=-0.166,95 \% \mathrm{Cl}:-.232,-.100)(9$ studies, total $n=5269)$ vs $>14$ years $(d=$ $0.132,95 \% \mathrm{Cl}[-.225,-.039], 5$ studies, total $n=3819$ ) explain the heterogeneity in the effect sizes ( $\mathrm{Q}$ (1) $=0.354, p=552)$. Finally, comparing adolescent's disclosure assessments interval $\leq 2$ years, $(d=-$ $0.098,95 \% \mathrm{Cl}[.191,-.005], 6$ studies, total $\mathrm{n}=1616)$ vs more than 2 years $(\mathrm{d}=-0.178,95 \% \mathrm{Cl}[.252$, .104], 9 studies, total $n=7791$ ), resulted in a similar effect size for the developmental decline in disclosure $(\mathrm{Q}(1)=1.732, \mathrm{p}=.188)$.

\#\#\#IGURE 5 AROUND HERE

\section{Adolescent secrecy}

In the 6 studies on secrecy, the developmental change in secrecy ranged from $d=-0.076$ to $d=0.591$ (Figure 6). Summarizing these results, we found a statistically significant small to medium increase over time $(\mathrm{d}=.194,95 \% \mathrm{Cl}[.031, .356], 6$ studies, total $\mathrm{N}=4,368)$. The fail-safe number is 160 . With 6 studies included in this meta-analysis, this exceeds Rosenthal (1979) threshold of 40 ( $N>5 k+10)$. Even though the homogeneity test indicated that there was statistically significant heterogeneity 
across the studies in terms of the effect sizes: $Q(8)=131.047, p<.001$ this analysis did not meet the criterion of at least 4 studies for each category to be compared. Therefore, moderation analyses could not be conducted.

\#\#\#IGURE 6 AROUND HERE

\section{Discussion}

As adolescents grow up, one of the important developmental tasks is to individuate themselves and becoming more autonomous from parents. As such, they increasingly spend their leisure time outside, in activities which are not supervised by parents, and of which often parents are unaware. (Larson, Richards, M oneta, Holmbeck, \& Duckett, 1996; Stattin \& Kerr, 2000). At the same time, parents are faced with the challenging task of monitoring these activities, while at the same time facilitating and supporting their children's needs of reaching an increased autonomy, and maintaining connectedness. In order to realign their relationship, both the parent and the adolescent thus have to renegotiate the communication processes that involve expecting and sharing information regarding leisure time activities (Branje, Laursen, \& Collins, 2012; Keijsers \& Poulin, 2013).

We used a meta-analytic approach to describe the normative developmental changes and summarize the empirical literature on developmental changes in parent-adolescent communication regarding leisure activities in community samples. Specifically, we included in the analysis all longitudinal studies published between 2000 and 2015 on adolescent's disclosure and secrecy, control, knowledge and solicitation, in community samples. This resulted in the inclusion of 31 studies, on which mean developmental changes and moderation effects were estimated.

\section{Developmental changes in parent-child communication}


In line with our expectations, and with the assumption that children experience an increased need of independence and of individuation when moving from middle childhood to adolescence, results showed a normative decline in adolescent's disclosure, parental control, knowledge and solicitation, and an increase in the degree of adolescent's secrecy. The most pronounced developmental changes were found for parental control $(d=-.395)$, followed by parental knowledge $(d=-.245)$ and solicitation (based on parents' reports, $d=-0.242$ ) and adolescent secrecy $(d=.194)$ and disclosure $(d=-.147)$.

These results suggest that parents seem to acknowledge early adolescent needs of privacy particularly by decreasing efforts of controlling access to information regarding leisure time (i.e., demanding that adolescent tell them where they go, with whom, etc.), and fit nicely with studies that apply a social domain perspective on parent-child relationships, which indicate that parents themselves consider that parental authority becomes less legitimate (Smetana, Crean, \& CampioneBarr, 2005). Interestingly, whereas parents reported a decrease in solicitation ( $d=-0.242)$ no such developmental change was observed in adolescents' reports $(d=0.038)$, a significant moderation effect in our meta-analytic study. Adolescents and parents seem to see the same world through different lenses. One potential explanation can be found in the impact that solicitation has. As the legitimacy of parental involvement in personal and multifaceted domains decreases during adolescence (Smetana et al., 2005), the potentially negative impact of parents asking questions may increase, for instance, if parental attempts to be involved are perceived as a violation of adolescents' privacy (Hawk, Hale, Raaijmakers, \& M eeus, 2008). To consider this mismatch in the parent and in the adolescent perspective, currently supported with a meta-analytic finding, may have important implications for parenting programs and adolescents' intervention programs aimed at promoting a positive communication between the two.

At the same time, adolescent themselves are not passive recipients of parenting, but through managing the information their parents get (Keijsers \& Laird, 2010; Marshall, Tilton-Weaver, $\&$ Bosdet, 2005), they may play an active role in shaping and changing the communication process. 
Indeed, whereas adolescents decreased their disclosure, their secrecy increased over the course of adolescence. There are several potential explanations of these findings. One group of explanations suggests that adolescents may strategically use information management, such as lying, disclosing only partial truths, or keeping secrets in order to establish their autonomous self (Finkenauer, Frijns, Engels, \& Kerkhof, 2005; Keijsers et al., 2010) to assert power or manipulate parents (Kerr, Stattin, Biesecker, \& Ferrer-Wreder, 2003), or avoid disapproval (M arshall et al., 2005). At the same time, as children grow up an increasing amount of aspects of their lives become private or personal, and rather than being an active strategy, disclosure may also decline because there is no longer an obligation to disclosure such information to parents (Smetana, Metzger, Gettman \& Campione-Barr, 2006), because adolescents express a greater desire for individuation and independence or because the opportunities to talk decrease, for example, as the result of a an increase in time spent with friends in out of home activities.

Finally, changes in parental monitoring efforts, specifically their solicitation attempts, or changes in the relationship quality may affect adolescent's willingness to disclose and form a driving force behind these developmental changes in disclosure (Keijsers et al., 2016).

Lastly, this meta-analytical study indicated a decline in parental knowledge ( $d=-.245)$. One likely explanation, is that this decline is the result of the developmental changes in adolescent's disclosure and monitoring practices (Keijsers et al., 2016). This decline in parental knowledge may have important implications for child well-being, as it is only through being informed that parents can be the source of support and guidance that a developing adolescent needs. Parental knowledge has been frequently linked to adolescent delinquency and norm breaking in the monitoring literature. However, also when it comes to internalizing problems, and other mental health problems, parents are often not well-informed, and there is a concerning long delay between the first display of symptoms, and receiving actual treatment (Raven, Jörg, Visser, Oldehinkel, \& Schoevers, 2017). Future research is thus needed to understand what the driving forces are behind 
these developmental declines in parent-child communication, and how they may impact the health and well-being of adolescents.

\section{Limitations and future directions}

Even though this is, to the best of our knowledge, the first meta-analytical summary of the empirical literature on parent-child communication, it is not without limitations. First, it has to be acknowledged that overall the number of longitudinal studies included in the meta-analysis, and currently available in this field, is limited, and this may have downplayed the opportunity of detecting more significant moderating effects. Second, only a few papers explored the role of candidate moderating variables (e.g. informant's gender, distinction between mother and father, and country), preventing a more extended analysis of other potentially relevant variables beside demographic ones. Beside sociodemographic variables, the research in this field has not yet extended the focus of the analysis on other relevant moderating variables, for instance, pertaining to personality and temperamental differences in children and parents (Pluess et al., 2017) which could partially moderate the impact that each member of the dyad has on the other. These moderating mechanisms, extensively explored in parent-infant interaction studies (Slagt, Dubas, Dekovic, \& van Aken, 2016), have still to be integrated in the parental monitoring framework. Lastly, it has to be acknowledged that meta-analytic information on changes in parent-child communication across time does not inform on motivation behind such changes, and does not allow to identify mediation mechanisms responsible for this process. Other candidate variables, as parenting style, could be more extensively explored. For example, studies reported that parenting styles dimension may partially influence the degree to which adolescents disclose information about their everyday life activities, with high parental responsiveness and behavioral control, and low psychological control, reported to create a family climate in which adolescents are more prone to speak about their whereabouts (Soenens, Vansteenkiste, Luyckx, \& Goossens, 2006), suggesting that taking into 
account other parenting variables may help in better understanding changes in communication across time.

Notwithstanding these limitations, which suggest at the same time new directions for future studies, our meta-analysis adds to the existing literature on developmental changes in parent - child relationships in three ways. First, our results provide further support to the hypothesized decline in the flow of the parent-child communication as a normative and developmental process. This decline, consistently reported across all scales, support the idea that knowledge, solicitation and control, and secrecy and disclosure, reflect a broader and cohesive parent-child communication process. At the same time, the most pronounced changes were a developmental decline in parental control and parental knowledge and a developmental increase in adolescent secrecy. Second, the current metaanalysis suggests that parental and adolescent perception of developmental changes in communication processes may differ from each other, with parents reporting a decrease in their level of solicitation, which adolescents do not perceive. This suggests that differences in the parent and adolescent perception is a normative developmental aspect and should be considered by practitioners and clinicians working for the improvement of the parent-child communication quality. Third, the high heterogeneity in study results emerged at a meta-analytical level clearly call for a more in depth exploration of putative moderation mechanisms, yet to be identified, able to better explain individual differences in developmental changes in parent-child communication regarding adolescent leisure activities.

\section{References}

Branje, S., Laursen, B., \& Collins, W. A. (2012). Parent-child communication during adolescence. Routledge handbook of family communication, 271-286. doi: 10.4324/9780203848166.ch17

Achenbach, T. M. (2006). As others see us: Clinical and research implications of cross-informant correlations for psychopathology. Current Directions in Psychological Science, 15(2). doi: $10.1111 / j .0963-7214.2006 .00414 . x$ 
Boislard P, M.-A., \& Poulin, F. (2011). Individual, familial, friends-related and contextual predictors of early sexual intercourse. Journal of Adolescence, 34(2), 289-300. doi:10.1016/i.adolescence.2010.05.002

Borenstein, M., Hedges, L. V., Higgins, J. P. T., \& Rothstein, H. R. (2010). A basic introduction to fixedeffect and random-effects models for meta-analysis. Research Synthesis M ethods, 1, 97-111. doi: 10.1002/jrsm.12

Borenstein, M ., Rothstein, D., \& Cohen, J. (2005). Comprehensive M eta-analyisis: A Computer Program for Research Synthesis. (Biostat, Englewood, NJ. ed.): Biostat.

Branje, S., Finkenauer, C., \& M eeus, W. (2008). M odeling interdependence using the social relations model: The investment model in family relationships. In N. A. Card, J. P. Seling, \& T. D. Little (Eds). M odeling dyadic and interdependent data in the developmental and behavioral sciences (, 277-308). New York, NY: Routledge

Branje, S., Laursen, B., \& Collins, W. A. (Eds.). (2013). Parent-child communication during adolescence (2nd ed.). New York: Routledge. doi: 10.1080/02673843.2014.884006

Cheung, C. S. S., Pomerantz, E. M., \& Dong, W. (2013). Does adolescents' disclosure to their parents matter for their academic adjustment? Child Development, 84(2), 693-710. doi:10.1111/j.1467-8624.2012.01853.x

Collins, W. A. (1990). Parent-child relationships in the transition to adolescence: Continuity and change in interaction, affect, and cognition. In T. P. Gullotta, R. Montemayor \& G. R. Adams (Eds.), From childhood to adolescence: A transitional period? (pp. 85-106). Thousand Oaks, CA: Sage. Collins, W. A., \& Laursen, B. (2004). Parent-adolescent relationships and influences. In R. M. Lerner \& L. Steinberg (Eds.), Handbook of adolescent psychology (pp. 331-361). Hoboken, NJ: John, Wiley \& Sons. doi: 10.1002/9780471726746.ch11.

Collins, W. A., \& Steinberg, L. (2006). Adolescent development in interpersonal context. In N. Eisenberg (Ed.), Handbook of child psychology: Vol. 3. Social, emotional, and personality development (6th ed., pp. 1003-1067). Hoboken, NJ: Wiley. 
Creemers, H. E., Buil, J. M ., van Lier, P. A. C., Keijsers, L., M eeus, W., Koot, H. M., \& Huizink, A. C. (2015). Early onset of cannabis use: Does personality modify the relation with changes in perceived parental involvement? Drug and Alcohol Dependence, 146(1), 61-67. doi:10.1016/j.drugalcdep.2014.11.004

Crouter, A. C., \& Head, M. R. (2002). Parental monitoring and knowledge of children. In M . H. Bornstein (Ed.). Handbook of parenting, volume 5 (3, 461-483). Mahwah, NJ: Laurence Erlbaum Associates

De Los Reyes, A., \& Kazdin, A. E. (2009). Identifying evidence-based interventions for children and adolescents using the range of possible changes model: A meta-analytic illustration. Behavior Modification, 33(5), 583-617. doi: 10.1177/0145445509343203

De Los Reyes, A., Goodman, K. L., Kliewer, W., \& Reid-Quinones, K. (2010). The longitudinal consistency of mother-child reporting discrepancies of parental monitoring and their ability to predict child delinquent behaviors two years later. Journal of Youth and Adolescence, 39(12), 14171430. doi: 10.1007/s10964-009-9496-7.

De Los Reyes, A., Goodman, K. L., Kliewer, W., \& Reid-Quinones, K. R. (2008). Whose depression relates to discrepancies? Testing relations between informant characteristics and informant discrepancies from both informants' perspectives. Psychological Assessment, 20(2), 139149. doi: $\underline{10.1037 / 1040-3590.20 .2 .139}$

De Los Reyes, A., Henry, D. B., Tolan, P. H., \& Wakschlag, L. S. (2009). Linking informant discrepancies to observed variations in young children's disruptive behavior. Journal of Abnormal Child Psychology, 37(5), 637-652. doi: 10.1007/s10802-009-9307-3

Dishion, T. J ., \& M cM ahon, R. J. (1998). Parental monitoring and the prevention of child and adolescent problem behavior: A conceptual and empirical formulation. Clinical Child and Family Psychology Review, 1(1), 61-75. doi: 10.1023/A:1021800432380 
Finkenauer, C., Frijns, T., Engels, R. C., \& Kerkhof, P. (2005). Perceiving concealment in relationships between parents and adolescents: Links with parental behavior. Personal Relationships, 12(3), 387-406. doi: 10.1111/j.1475-6811.2005.00122.x

Fletcher, A. C., Steinberg, L., \& Williams-Wheeler, M. (2004). Parental influences on adolescent problem behavior: revisiting Stattin and Kerr. Child Development, 75(3), 781-796. doi: $10.1111 / j .1467-8624.2004 .00706 . x$

Frijns, T., Keijsers, L., Branje, S., \& M eeus, W. (2010). What parents don't know and how it may affect their children: Qualifying the disclosure-adjustment link. Journal of Adolescence, 33, 261-270. http://dx.doi.org/10.1016/j.adolescence.2009.05.010.

Fu, R., Gartlehner, G., Grant, M., Shamliyan, T., Sedrakyan, A., Wilt, T. J., . . . Ismaila, A. (2011). Conducting quantitative synthesis when comparing medical interventions: AHRQ and the Effective Health Care Program. Journal of Clinical Epidemiology, 64(11), 1187-1197. doi: 10.1016/j.jclinepi.2010.08.010

Garthe, R. C., Sullivan, T., \& Kliewer, W. (2015). Longitudinal relations between adolescent and parental behaviors, parental knowledge, and internalizing behaviors among urban adolescents. Journal of Youth and Adolescence, 44(4), 819-32. doi:10.1007/s10964-014-0112-0

Giannotta, F., Ortega, E., \& Ciairano, S. (2011). A two-year follow-up investigation of parenting and peer influences on tobacco use onset among Italian early adolescents. European Journal of Developmental Psychology, 8(5), 573-586. doi:10.1080/17405629.2011.579408

Glatz, T., Stattin, H., \& Kerr, M. (2011). Parents' reactions to youths' hyperactivity, impulsivity, and attention problems. Journal of Abnormal Child Psychology, 39(8), 1125. doi: 10.1007/s10802$011-9541-3$

Glueck, S., \& Glueck, E. (1950). Unraveling juvenile delinquency. Cambridge, M A: Harvard University Press 
Gottfredson, M. R., \& Hirschi, T. (1990). A General Theory of Crime. Stanford, CA: Stanford University Press.

Hamza, C. A., \& Willoughby, T. (2011). Perceived parental monitoring, adolescent disclosure, and adolescent depressive symptoms: A longitudinal examination. Journal of Youth and Adolescence, 40(7), 902-915. doi: 10.1007/s10964-010-9604-8

Han, Y., Grogan-Kaylor, A., Bares, C., Ma, J., Castillo, M., \& Delva, J. (2012). Relationship between discordance in parental monitoring and behavioral problems among Chilean adolescents. Children and Youth Services Review, 34(4), 783-789. doi: 10.1016/i.childyouth.2012.01.005

Hawk, S. T., Hale III, W. W., Raaijmakers, Q. A., \& Meeus, W. (2008). Adolescents' perceptions of privacy invasion in reaction to parental solicitation and control. The Journal of Early Adolescence, 28(4), 583-608. doi: 10.1177/0272431608317611

Hawk, S. T., Keijsers, L., Frijns, T., Hale, W. W., Branje, S., \& M eeus, W. (2013). "I still haven't found what I'm looking for": parental privacy invasion predicts reduced parental knowledge.

Developmental Psychology, 49(7), 1286-98. doi:10.1037/a0029484

Janssen, H. J., Dekovi , M ., \& Bruinsma, G. J. N. (2014). Parenting and Time Adolescents Spend in Criminogenic Settings: A Between- and Within-person Analysis. British Journal of Criminology, 54(4), 551-567. doi:10.1093/bjc/azu032

Keijsers, L. (2016). Parental monitoring and adolescent problem behaviors: How much do we really know? International Journal of Behavioral Development, 40(3), 271-281. doi: $10.1177 / 0165025415592515$

Keijsers, L., Branje, S. J., Frijns, T., Finkenauer, C., \& M eeus, W. (2010). Gender differences in keeping secrets from parents in adolescence. Developmental Psychology, 46(1), 293. doi: $10.1037 / \mathrm{a} 0018115$

Keijsers, L., Branje, S., Hawk, S. T., Schwartz, S. J., Frijns, T., Koot, H. M., . . . Meeus, W. (2012). Forbidden friends as forbidden fruit: Parental supervision of friendships, contact with deviant 
peers, and adolescent delinquency. Child Development, 83(2), 651-666. doi: 10.1111/j.14678624.2011.01701.x

Keijsers, L., Branje, S. J. T., VanderValk, I. E., \& Meeus, W. (2010). Reciprocal Effects Between Parental Solicitation, Parental Control, Adolescent Disclosure, and Adolescent Delinquency. Journal of Research on Adolescence, 20(1), 88-113. doi:10.1111/j.1532-7795.2009.00631.x

Keijsers, L., Frijns, T., Branje, S. J. T., \& M eeus, W. (2009). Developmental links of adolescent disclosure, parental solicitation, and control with delinquency: moderation by parental support. Developmental Psychology, 45(5), 1314-1327. doi:10.1037/a0016693

Keijsers, L., \& Laird, R. D. (2010). Introduction to special issue. Careful conversations: Adolescents managing their parents' access to information. Journal of Adolescence, 33(2), 255-259. doi: 10.1016/j.adolescence.2009.10.009

Keijsers, L., \& Laird, R. D. (2014). Mother-adolescent monitoring dynamics and the legitimacy of parental authority. Journal of Adolescence, 37(5), 515-24. doi:10.1016/i.adolescence.2014.04.001

Keijsers, L., Loeber, R., Branje, S., \& M eeus, W. (2012). Parent-child relationships of boys in different offending trajectories: a developmental perspective. Journal of Child Psychology and Psychiatry, 53(12), 1222-1232. doi: 10.1111/j.1469-7610.2012.02585.x

Keijsers, L., \& Poulin, F. (2013). Developmental changes in parent-child communication throughout adolescence. Developmental Psychology, 49(12), 2301. doi: $\underline{10.1037 / a 0032217}$

Keijsers, L., Voelkle, M. C., Maciejewski, D., Branje, S., Koot, H., Hiemstra, M., \& M eeus, W. (2016). What drives developmental change in adolescent disclosure and maternal knowledge? Heterogeneity in within-family processes. Developmental Psychology, 52(12), 2057. doi: $10.1037 / \operatorname{dev} 0000220$

Kerr, M ., \& Stattin, H. (2000). What parents know, how they know it, and several forms of adolescent adjustment: further support for a reinterpretation of monitoring. Developmental Psychology, 36(3), 366. doi: 10.1037/0012-1649.36.3.366 
Kerr, M., Stattin, H., Biesecker, G., \& Ferrer-Wreder, L. (2003). Relationships With Parents and Peers in Adolescence. In I. B. Weiner (Ed.), Handbook of psychology (Vol. 4, 395-419). Hoboken, N): Wiley. doi: 10.1002/0471264385.wei0616

Kerr, M., Stattin, H., \& Burk, W. J. (2010). A Reinterpretation of Parental M onitoring in Longitudinal Perspective. Journal of Research on Adolescence, 20(1), 39-64. doi:10.1111/j.15327795.2009.00623.x

Kiesner, J., Dishion, T. J., Poulin, F., \& Pastore, M . (2009). Temporal Dynamics Linking Aspects of Parent Monitoring with Early Adolescent Antisocial Behavior. Social Development (Oxford, England), 18(4), 765- 784. doi:10.1111/j.1467-9507.2008.00525.x

Larson, R. W., Richards, M . H., M oneta, G., Holmbeck, G., \& Duckett, E. (1996). Changes in adolescents' daily interactions with their families from ages 10 to 18: Disengagement and transformation. Developmental Psychology, 32(4), 744. doi: 10.1037/0012-1649.32.4.744.

Larson, R., \& Richards, M. H. (1991). Daily companionship in late childhood and early adolescence: Changing developmental contexts. Child Development, 62(2), 284-300. doi: 10.1111/j.14678624.1991.tb01531.x

Lerner, R. M., \& Steinberg, L. D. (Eds.). (2009). Handbook of Adolescent Psychology. Volume 1: Individual Bases of Adolescent development (3rd ed.). Hoboken, N.J.: Wiley. doi: $10.1002 / 9780470479193$

Lionetti, F., Keijsers, L., Dellagiulia, A., \& Pastore, M. (2016). Evidence of factorial validity of parental knowledge, control and solicitation, and adolescent disclosure scales: When the ordered nature of likert scales matters. Frontiers in Psychology, 7:941. doi: 10.3389/fpsyg.2016.00941

Marshall, S. K., Tilton-Weaver, L. C., \& Bosdet, L. (2005). Information management: Considering adolescents' regulation of parental knowledge. Journal of Adolescence, 28(5), 633-647. doi: 10.1016/j.adolescence.2005.08.008

Masche, J. G. (2010). Explanation of normative declines in parents' knowledge about their adolescent children. Journal of Adolescence, 33(2), 271-284. doi: 10.1016/j.adolescence.2005.08.008 
Meeus, W. (2016). Adolescent psychosocial development: A review of longitudinal models and research. Developmental Psychology, 52(12), 1969. doi: 10.1037/dev0000243

Merrilees, C. E., Cummings, E. M., Goeke-M orey, M. C., Schermerhorn, A. C., Shirlow, P., \& Cairns, E. (2011). Parenting control in contexts of political violence: Testing bidirectional relations between violence exposure and control in post-accord Belfast. Parenting: Science and Practice, 11(4), 308-325. doi:10.1080/15295192.2011.613726

Moher, D., Liberati, A., Tetzlaff, J., Altman, D. G., \& Group, P. (2009). Preferred reporting items for systematic reviews and meta-analyses: the PRISM A statement. Plos M edicine, 6(7), e1000097. doi: 10.1371/journal.pmed.1000097

Muñoz, L. C., Pakalniskiene, V., \& Frick, P. J. (2011). Parental monitoring and youth behavior problems: moderation by callous-unemotional traits over time. European Child \& Adolescent Psychiatry, 20(5), 261-9. doi:10.1007/s00787-011-0172-6

Pasch, K. E., Stigler, M. H., Perry, C. L., \& Komro, K. A. (2010). Parents' and children's self-report of parenting factors: How much do they agree and which is more strongly associated with early adolescent alcohol use? Health Education Journal, 69(1), 31-42. doi: $10.1177 / 0017896910363325$

Patterson, G. R., \& Dishion, T. J. (1985). Contributions of families and peers to delinquency. Criminology, 23(1), 63-79. doi: 10.1111/j.1745-9125.1985.tb00326.x

Patterson, G. R., \& Stouthamer-Loeber, M. (1984). The correlation of family management practices and delinquency. Child Development, 55(4) 1299-1307. doi: 10.2307/1129999

Petronio, S. (2002). Boundaries of Privacy. Dialectics of Disclosure. Albany: State university New York Press.

Pettit, G. S., Laird, R. D., Dodge, K. A., Bates, J. E., \& Criss, M. M. (2001). Antecedents and behaviorproblem outcomes of parental monitoring and psychological control in early adolescence. Child development, 72(2), 583-598. 
Pluess, M., Assary, E., Lionetti, F., Lester, K. J., Krapohl, E., Aron, E. N., \& Aron, A. (2017). Environmental Sensitivity in Children: Development of the Highly Sensitive Child Scale and Identification of Sensitivity Groups. Developmental Psychology, 54(1), 55-70. doi: $10.1037 /$ dev0000406

Pomerantz, E. M., Qin, L., Wang, Q., \& Chen, H. (2011). Changes in early adolescents' sense of responsibility to their parents in the United States and China: Implications for their academic functioning. Child Development, 82(4), 1136-1151. doi: 10.1111/j.1467-8624.2011.01588.x.

Poulin, F., \& Denault, A. S. (2012). Other-Sex Friendships as a M ediator Between Parental M onitoring and Substance Use in Girls and Boys. Journal of Youth and Adolescence, 41(11), 1488-1501. doi:10.1007/s10964-012-9770-y

Qin, L., \& Pomerantz, E. M. (2013). Reciprocal pathways between American and Chinese early adolescents' sense of responsibility and disclosure to parents. Child Development, 84(6), 18871895. doi: $10.1111 /$ cdev.12088

Racz, S. J., \& McMahon, R. J. (2011). The relationship between parental knowledge and monitoring and child and adolescent conduct problems: A 10-year update. Clinical Child and Family Psychology Review, 14(4), 377-398. doi: 10.1007/s10567-011-0099-y.

Raven, D., Jörg, F., Visser, E., Oldehinkel, A., \& Schoevers, R. (2017). Time-to-treatment of mental disorders in a community sample of Dutch adolescents. A TRAILS study. Epidemiology and Psychiatric Sciences, 26(2), 177-188. doi: 10.1017/\$2045796016000226

Reynolds, E. K., M acPherson, L., Matusiewicz, A. K., Schreiber, W. M ., \& Lejuez, C. W. (2011).

Discrepancy between mother and child reports of parental knowledge and the relation to risk behavior engagement. Journal of Clinical Child and Adolescent Psychology, 40(1), 67-79. doi:10.1080/15374416.2011.533406

Rosenthal, R. (1979). The file drawer problem and tolerance for null results. Psychological bulletin, 86(3), 638 
Salafia, E. H. B., Gondoli, D. M ., \& Grundy, A. M. (2009). The longitudinal interplay of maternal warmth and adolescents' self-disclosure in predicting maternal knowledge. Journal of Research on Adolescence, 19(4), 654-668. doi:10.1111/i.1532-7795.2009.00615.x

Slagt, M., Dubas, J. S., Dekovic, M., \& van Aken, M. A. (2016). Differences in sensitivity to parenting depending on child temperament: A meta-analysis. Psychological Bulletin, 142(10), 1068. doi: $10.1037 /$ bul0000061

Smetana, J. (1989). Adolescents' and parents' reasoning about actual family conflict. Child Development, 60(5), 1052-1067. doi: 10.2307/1130779

Smetana, J. (2008). "It's 10 o'clock: Do you know where your children are?" Recent advances in understanding parental monitoring and adolescents' information management. Child Development Perspectives, 2(1), 19-25. doi: 10.1111/j.1750-8606.2008.00036.x

Smetana, J. G., \& Asquith, P. (1994). Adolescents' and parents' conceptions of parental authority and personal autonomy. Child Development, 65(4), 1147-1162. doi: 10.2307/1131311

Smetana, J., Crean, H. F., \& Campione-Barr, N. (2005). Adolescents' and parents' changing conceptions of parental authority. New Directions for Child and Adolescent Development, 2005(108), 3146. doi: $10.1002 / \mathrm{cd} .126$

Soenens, B., Vansteenkiste, M., Luyckx, K., \& Goossens, L. (2006). Parenting and adolescent problem behavior: An integrated model with adolescent self-disclosure and perceived parental knowledge as intervening variables. Developmental psychology, 42(2), 305.

Solís, M . V., Smetana, J., \& Comer, J. (2015). Associations among solicitation, relationship quality, and adolescents' disclosure and secrecy with mothers and best friends. Journal of Adolescence, 43, 193-205. doi: 10.1016/j.adolescence.2015.05.016.

Son, I. B., \& Choi, J. A. (2013). Parental knowledge trajectory and its relationships with parental warmth and adolescent disclosure for Korean adolescents. Children and Youth Services Review, 35(9), 1643-1649. doi: 10.1016/j.childyouth.2013.06.018 
Stattin, H., \& Kerr, M . (2000). Parental monitoring: A reinterpretation. Child Development, 71(4), 10721085. doi: $10.1111 / 1467-8624.00210$

Stattin, H., Persson, S., Burk, W. J., \& Kerr, M. (2011). Adolescents' Perceptions of the Democratic Functioning in their Families. European Psychologist, 16(1), 32-42. doi:10.1027/1016$9040 / a 000039$

Stavrinides, P., Georgiou, S., \& Demetriou, A. (2010). Longitudinal associations between adolescent alcohol use and parents' sources of knowledge. The British Journal of Developmental Psychology, 28(Pt 3), 643-655. doi:10.1348/026151009X466578

Stavrinides, P., Nikiforou, M., \& Georgiou, S. (2015). Do mothers know? Longitudinal associations between parental knowledge, bullying, and victimization. Journal of Social and Personal Relationships, 32(2), 180-196. doi: 10.1177/0265407514525889

Stouthamer-Loeber, M., \& Loeber, R. (1986). Boys who lie. Journal of Abnormal Child Psychology, 14(4), 551-564. doi: 10.1007/BF01260523

Strandberg, A. K., Bodin, M. C., \& Romelsjö, A. (2014). Gender differences in the prediction of parental servings of alcohol to adolescents and youth drunkenness. Substance Use $\&$ M isuse, 49(14), 1857-66. doi:10.3109/10826084.2014.913628

Tilton-Weaver, L. (2014). Adolescents' information management: Comparing ideas about why adolescents disclose to or keep secrets from their parents. Journal of Youth and Adolescence, 43(5), 803-813. doi: 10.1007/s10964-013-0008-4

Tilton-Weaver, L., Kerr, M., Pakalniskeine, V., Tokic, A., Salihovic, S., \& Stattin, H. (2010). Open up or close down: How do parental reactions affect youth information management? Journal of Adolescence, 33(2), 333-346. doi:10.1016/j.adolescence.2009.07.011

Van der Giessen, D., Branje, S., Keijsers, L., Van Lier, P. A., Koot, H. M., \& M eeus, W. (2014). Emotional variability during mother-adolescent conflict interactions: Longitudinal links to adolescent disclosure and maternal control. Journal of Adolescence, 37(1), 23-31. doi: 10.1016/j.adolescence.2013.10.007 
Van der Zwaluw, C. S., Engels, R. C. M. E., Vermulst, a a, Franke, B., Buitelaar, J., Verkes, R. J., \& Scholte, R. H. J. (2010). Interaction between dopamine D2 receptor genotype and parental rulesetting in adolescent alcohol use: evidence for a gene-parenting interaction. M olecular Psychiatry, 15(7), 727-35. doi:10.1038/mp.2009.4

Waizenhofer, R. N., Buchanan, C. M., \& Jackson-Newsom, J. (2004). M others' and fathers' knowledge of adolescents' daily activities: its sources and its links with adolescent adjustment. Journal of Family Psychology, 18(2), 348-360. doi: $\underline{10.1037 / 0893-3200.18 .2 .348}$

Wang, Q., Pomerantz, E. M., \& Chen, H. (2007). The role of parents' control in early adolescents' psychological functioning: A longitudinal investigation in the United States and China. Child Development, 78(5), 1592-1610. doi: 10.1111/j.1467-8624.2007.01085.x

Weisz, J. R., M cCarty, C. A., \& Valeri, S. M. (2006). Effects of psychotherapy for depression in children and adolescents: A meta-analysis. Psychological Bulletin, 132(1), 132-149. doi: $\underline{10.1037 / 0033-2909.132 .1 .132}$

Willoughby, T., \& Hamza, C. A. (2011). A longitudinal examination of the bidirectional associations among perceived parenting behaviors, adolescent disclosure and problem behavior across the high school years. Journal of Youth and Adolescence, 40(4), 463-78. doi:10.1007/s10964-010$9567-9$

Yungstrom, E. A., Findling, R. L., \& Calabrese, J. R. (2003). Who are the comorbid adolescents? Agreement between psychiatric diagnosis, youth, parent, and teacher report. Journal of Abnormal Child Psychology, 31(3), 231-245. doi: 10.1023/A:1023244512119 
Table 1 Studies included in the meta-analysis. Country, measures used, presence of subsamples, type of informant, time span covered by the data collection and adolescents mean age are reported for each study.

\begin{tabular}{|c|c|c|c|c|c|c|c|c|}
\hline & References & $\begin{array}{c}\text { Name of the Study } \\
\text { or Country }\end{array}$ & Overlapping Dataset & Measure & Subsample & Informant $^{1}$ & $\begin{array}{l}\text { Time Span } \\
\text { (in years) }\end{array}$ & $\begin{array}{l}\text { Adolescents } \\
\text { Mean Age } \\
\text { (1st Assess.) }\end{array}$ \\
\hline \multirow{2}{*}{1} & \multirow{2}{*}{ (Boislard \& Poulin, 2011) } & \multirow{2}{*}{ Canada } & $\begin{array}{c}\text { (Kiesner, Dishion, Poulin, \& } \\
\text { Pastore, 2009) }\end{array}$ & $\begin{array}{l}\text { Disclosure } \\
\text { Parental Control }\end{array}$ & Urban & \multirow{2}{*}{ AP } & \multirow{2}{*}{---} & \multirow[t]{2}{*}{ 年 } \\
\hline & & & (Keijsers \& Poulin, 2013) & $\begin{array}{l}\text { Disclosure } \\
\text { Parental Control }\end{array}$ & Suburban & & & \\
\hline 2 & $\begin{array}{c}\text { (Cheung, Pomerantz, \& } \\
\text { Dong, 2013) }\end{array}$ & USA - CHINA & --- & Disclosure & $\begin{array}{c}\text { USA } \\
\text { Chinese }\end{array}$ & AP & 2 & $\begin{array}{l}12.78 \\
12.69 \\
\end{array}$ \\
\hline 3 & (Creemers et al., 2015) & $\begin{array}{l}\text { The Netherlands - } \\
\text { RADAR }\end{array}$ & --- & Parental Control & n.a. & AP & 2 & 14 \\
\hline 4 & $\begin{array}{l}\text { (Garthe, Sullivan, \& } \\
\text { Kliewer, 2015) }\end{array}$ & USA & --- & $\begin{array}{l}\text { Disclosure } \\
\text { Parental } \\
\text { Knowledge }\end{array}$ & n.a. & $\begin{array}{c}\text { AP } \\
\text { Composite } \\
\text { measure: } \\
\text { caregiver and } \\
\text { adolescent }\end{array}$ & 1 & missing \\
\hline 5 & $\begin{array}{l}\text { (Giannotta, Ortega, \& } \\
\text { Ciairano, 2011) }\end{array}$ & Italy & --- & $\begin{array}{l}\text { Parental } \\
\text { Knowledge }\end{array}$ & n.a. & AP & 3 & 11.14 \\
\hline 6 & $\begin{array}{c}\text { (Glatz, Stattin, \& Kerr, } \\
\text { 2011) }\end{array}$ & Sweden & --- & $\begin{array}{l}\text { Parental Control } \\
\text { Parental } \\
\text { Solicitation } \\
\end{array}$ & n.a. & PA & 4 & 11 \\
\hline 7 & $\begin{array}{c}\text { (Hamza \& Willoughby, } \\
2011) *\end{array}$ & Canada (Ontario) & $\begin{array}{c}\text { (Willoughby \& Hamza, } \\
\text { 2011) }\end{array}$ & $\begin{array}{l}\text { Disclosure } \\
\text { Parental Control }\end{array}$ & $\begin{array}{c}\text { Female } \\
\text { Male }\end{array}$ & AP & 3 & 14 \\
\hline \multirow{2}{*}{8} & \multirow{2}{*}{$\begin{array}{c}\text { (Hawk, Hale, } \\
\text { Raaijmakers, \& M eeus, } \\
\text { 2008) }\end{array}$} & \multirow{2}{*}{$\begin{array}{l}\text { The Netherlands - } \\
\text { CONAM ORE }\end{array}$} & \multirow{2}{*}{$\begin{array}{c}\text { (Keijsers, Frijns, Branje, \& } \\
\text { Meeus, 2009) }\end{array}$} & Parental Control & $\begin{array}{c}\text { Male } \\
\text { Female }\end{array}$ & \multirow{2}{*}{ AP } & \multirow{2}{*}{---} & \multirow[t]{2}{*}{--- } \\
\hline & & & & $\begin{array}{l}\text { Parental } \\
\text { Solicitation }\end{array}$ & n.a. & & & \\
\hline
\end{tabular}




\begin{tabular}{|c|c|c|c|c|c|c|c|c|}
\hline & References & $\begin{array}{l}\text { Name of the Study } \\
\text { or Country }\end{array}$ & Overlapping Dataset & Measure & Subsample & Informant $^{1}$ & $\begin{array}{l}\text { Time Span } \\
\text { (in years) }\end{array}$ & $\begin{array}{c}\text { Adolescents } \\
\text { Mean Age } \\
\text { (1st Assess.) }\end{array}$ \\
\hline \multirow{6}{*}{9} & \multirow{6}{*}{ (Hawk et al., 2013) } & \multirow{6}{*}{$\begin{array}{l}\text { The Netherlands - } \\
\text { RADAR }\end{array}$} & \multirow{6}{*}{---} & Parental & \multirow{6}{*}{ n.a. } & MA & \multirow{6}{*}{2} & \multirow{6}{*}{13} \\
\hline & & & & Knowledge & & FA & & \\
\hline & & & & & & AM & & \\
\hline & & & & Secrecy & & MA & & \\
\hline & & & & & & $\mathrm{AF}$ & & \\
\hline & & & & & & FA & & \\
\hline 10 & $\begin{array}{c}\text { (Janssen, Dekovi , \& } \\
\text { Bruinsma, 2014) }\end{array}$ & SPAN & --- & Parental Control & n.a. & $A P$ & 2 & 14.3 \\
\hline \multirow{2}{*}{11} & \multirow{2}{*}{ (Keijsers \& Laird, 2014) } & \multirow{2}{*}{ USA } & \multirow{2}{*}{---} & $\begin{array}{l}\text { Disclosure } \\
\text { Secrecy }\end{array}$ & n.a. & AM & \multirow{2}{*}{1} & \multirow{2}{*}{12.4} \\
\hline & & & & $\begin{array}{l}\text { Parental } \\
\text { Solicitation }\end{array}$ & n.a. & MA & & \\
\hline \multirow{3}{*}{12} & \multirow{3}{*}{$\begin{array}{c}\text { (Keijsers \& Poulin, 2013) } \\
*\end{array}$} & \multirow{3}{*}{ Canada } & (Boislard P \& Poulin, 2011) & $\begin{array}{l}\text { Disclosure } \\
\text { Parental Control }\end{array}$ & \multirow{3}{*}{ n.a. } & \multirow{3}{*}{ AP } & \multirow{3}{*}{7} & \multirow{3}{*}{12.38} \\
\hline & & & (Poulin \& Denault, 2012) & $\begin{array}{l}\text { Parental } \\
\text { Knowledge }\end{array}$ & & & & \\
\hline & & & --- & $\begin{array}{l}\text { Parental } \\
\text { Solicitation } \\
\text { Secrecy }\end{array}$ & & & & \\
\hline \multirow{4}{*}{13} & \multirow{4}{*}{ (Keijsers et al., 2009) * } & \multirow{4}{*}{$\begin{array}{l}\text { The Netherlands - } \\
\text { CONAM ORE }\end{array}$} & $\begin{array}{c}\text { (Keijsers, Branje, } \\
\text { VanderValk, \& M eeus, } \\
\text { 2010) }\end{array}$ & Disclosure & & & \multirow{4}{*}{2} & \multirow{4}{*}{13.2} \\
\hline & & & --- & $\begin{array}{l}\text { Parental } \\
\text { Solicitation } \\
\text { Parental Control } \\
\end{array}$ & n.a. & MA & & \\
\hline & & & $\begin{array}{c}\text { (Keijsers, Branje, } \\
\text { VanderValk, et al., 2010) }\end{array}$ & Parental Control & \multirow[t]{2}{*}{ n.a. } & \multirow[t]{2}{*}{ FA } & & \\
\hline & & & --- & Disclosure & & & & \\
\hline
\end{tabular}




\begin{tabular}{|c|c|c|c|c|c|c|c|c|}
\hline & References & $\begin{array}{l}\text { Name of the Study } \\
\text { or Country }\end{array}$ & Overlapping Dataset & Measure & Subsample & Informant $^{1}$ & $\begin{array}{l}\text { Time Span } \\
\text { (in years) }\end{array}$ & $\begin{array}{l}\text { Adolescents } \\
\text { Mean Age } \\
\text { (1st Assess.) }\end{array}$ \\
\hline & & & & $\begin{array}{l}\text { Parental } \\
\text { Solicitation }\end{array}$ & & & & \\
\hline & & & & Disclosure & & & & \\
\hline & & & $\begin{array}{c}\text { (Keijsers, Branje, } \\
\text { VanderValk, et al., 2010) }\end{array}$ & $\begin{array}{l}\text { Parental } \\
\text { Solicitation }\end{array}$ & n.a. & AP & 3 & \\
\hline & & & (Hawk et al., 2008) & Parental Control & & & & \\
\hline \multirow[b]{2}{*}{14} & \multirow{2}{*}{$\begin{array}{c}\text { (Keijsers, Branje, Frijns, } \\
\text { Finkenauer, \& Meeus, } \\
\text { 2010) }\end{array}$} & \multirow{2}{*}{$\begin{array}{l}\text { The Netherlands - } \\
\text { CONAM ORE }\end{array}$} & \multirow[b]{2}{*}{---} & \multirow[b]{2}{*}{ Secrecy } & Male & \multirow[b]{2}{*}{ AP } & \multirow[b]{2}{*}{3} & \multirow[b]{2}{*}{13.2} \\
\hline & & & & & Female & & & \\
\hline \multirow{7}{*}{15} & \multirow{7}{*}{$\begin{array}{c}\text { (Keijsers, Branje, } \\
\text { VanderValk, et al., 2010) }\end{array}$} & \multirow{7}{*}{$\begin{array}{l}\text { The Netherlands - } \\
\text { CONAM ORE }\end{array}$} & \multirow{3}{*}{ (Keijsers et al., 2009) } & \multirow{3}{*}{$\begin{array}{l}\text { Disclosure } \\
\text { Parental Control } \\
\text { Parental } \\
\text { Solicitation }\end{array}$} & \multirow{3}{*}{ n.a. } & $\mathrm{MA}$ & \multirow{3}{*}{--- } & \multirow{3}{*}{--- } \\
\hline & & & & & & FA & & \\
\hline & & & & & & $A P$ & & \\
\hline & & & \multirow{4}{*}{--- } & \multirow{4}{*}{$\begin{array}{l}\text { Parental } \\
\text { Knowledge }\end{array}$} & $\begin{array}{l}\text { Male } \\
\text { Female }\end{array}$ & MA & \multirow{4}{*}{1} & \multirow{4}{*}{14.2} \\
\hline & & & & & $\begin{array}{l}\text { Male } \\
\text { Female }\end{array}$ & FA & & \\
\hline & & & & & Male & $\Delta \mathrm{P}$ & & \\
\hline & & & & & Female & $A P$ & & \\
\hline \multirow[t]{2}{*}{16} & \multirow[t]{2}{*}{ (Keijsers et al., 2012) } & \multirow{2}{*}{$\begin{array}{l}\text { The Netherlands - } \\
\text { RADAR }\end{array}$} & $\begin{array}{c}\text { (Van der Giessen et al., } \\
\text { 2014) }\end{array}$ & \multirow[t]{2}{*}{ Parental Control } & \multirow[t]{2}{*}{ n.a. } & MA & --- & --- \\
\hline & & & --- & & & FA & 2 & 13 \\
\hline \multirow{2}{*}{17} & \multirow{2}{*}{$\begin{array}{c}\text { (Kerr, Stattin, \& Burk, } \\
\text { 2010)* }\end{array}$} & \multirow{2}{*}{ Sweden } & $\begin{array}{c}\text { (Stattin, Persson, Burk, \& } \\
\text { Kerr, 2011) }\end{array}$ & $\begin{array}{l}\text { Disclosure } \\
\text { Parental } \\
\text { Knowledge }\end{array}$ & \multirow{2}{*}{ n.a. } & \multirow{2}{*}{ PA } & \multirow{2}{*}{2} & \multirow{2}{*}{13.51} \\
\hline & & & --- & $\begin{array}{l}\text { Parental Control } \\
\text { Parental } \\
\text { Solicitation }\end{array}$ & & & & \\
\hline
\end{tabular}




\begin{tabular}{|c|c|c|c|c|c|c|c|c|}
\hline & References & $\begin{array}{c}\text { Name of the Study } \\
\text { or Country }\end{array}$ & Overlapping Dataset & Measure & Subsample & Informant $^{1}$ & $\begin{array}{c}\text { Time Span } \\
\text { (in years) }\end{array}$ & $\begin{array}{l}\text { Adolescents } \\
\text { Mean Age } \\
\text { (1st Assess.) }\end{array}$ \\
\hline & & & $\begin{array}{c}\text { (Tilton-Weaver et al., } \\
\text { 2010) }\end{array}$ & $\begin{array}{l}\text { Disclosure } \\
\text { Parental } \\
\text { Knowledge }\end{array}$ & & & & \\
\hline & & & --- & $\begin{array}{l}\text { Parental Control } \\
\text { Parental } \\
\text { Solicitation }\end{array}$ & n.a. & AP & & \\
\hline \multirow{4}{*}{18} & \multirow{4}{*}{ (Kiesner et al., 2009)* } & \multirow{4}{*}{ Italy - Canada } & \multirow{3}{*}{---} & \multirow{2}{*}{$\begin{array}{l}\text { Parental } \\
\text { Solicitation }\end{array}$} & Italian & $\begin{array}{l}\mathrm{AP} \\
\mathrm{PA}\end{array}$ & \multirow{4}{*}{1} & 14.11 \\
\hline & & & & & Canadian & AP & & 14.55 \\
\hline & & & & \multirow{2}{*}{$\begin{array}{l}\text { Disclosure } \\
\text { Parental Control }\end{array}$} & Italian & $\begin{array}{l}\mathrm{AP} \\
\mathrm{PA}\end{array}$ & & 14.11 \\
\hline & & & (Boislard P \& Poulin, 2011) & & Canadian & $\begin{array}{l}\mathrm{AP} \\
\mathrm{PA}\end{array}$ & & 14.55 \\
\hline 19 & (M asche, 2010)** & --- & --- & --- & --- & --- & --- & --- \\
\hline 20 & (M errilees et al., 2011) & Ireland & --- & Parental Control & n.a. & $\begin{array}{l}\mathrm{AM} \\
\mathrm{MA}\end{array}$ & 1 & 13.61 \\
\hline 21 & $\begin{array}{c}\text { (M uñoz, Pakalniskiene, } \& \\
\text { Frick, 2011) }\end{array}$ & USA & --- & $\begin{array}{l}\text { Parental Control } \\
\text { Parental } \\
\text { Solicitation }\end{array}$ & n.a. & MA & 1 & 14.5 \\
\hline 22 & (Poulin \& Denault, 2012) & Canada & (Keijsers \& Poulin, 2013) & $\begin{array}{l}\text { Parental } \\
\text { Knowledge }\end{array}$ & n.a. & AP & --- & --- \\
\hline \multirow[b]{2}{*}{23} & \multirow{2}{*}{$\begin{array}{c}\text { (Reynolds, M acPherson, } \\
\text { Matusiewicz, Schreiber, } \\
\text { \& Lejuez, 2011) }\end{array}$} & \multirow[b]{2}{*}{ USA } & \multirow[b]{2}{*}{---} & \multirow{2}{*}{$\begin{array}{l}\text { Parental } \\
\text { Knowledge }\end{array}$} & \multirow[b]{2}{*}{ n.a. } & $A P$ & \multirow[b]{2}{*}{1} & \multirow[b]{2}{*}{11.03} \\
\hline & & & & & & MA & & \\
\hline \multirow[b]{2}{*}{24} & \multirow{2}{*}{$\begin{array}{l}\text { (Salafia, Gondoli, \& } \\
\text { Grundy, 2009) }\end{array}$} & \multirow[b]{2}{*}{ USA } & \multirow[b]{2}{*}{---} & \multirow{2}{*}{$\begin{array}{l}\text { Disclosure } \\
\text { Parental } \\
\text { Knowledge }\end{array}$} & \multirow[b]{2}{*}{ n.a. } & AM & \multirow[b]{2}{*}{3} & \multirow{2}{*}{11.65} \\
\hline & & & & & & MA & & \\
\hline
\end{tabular}




\begin{tabular}{|c|c|c|c|c|c|c|c|c|}
\hline & References & $\begin{array}{c}\text { Name of the Study } \\
\text { or Country }\end{array}$ & Overlapping Dataset & Measure & Subsample & Informant $^{1}$ & $\begin{array}{c}\text { Time Span } \\
\text { (in years) }\end{array}$ & $\begin{array}{l}\text { Adolescents } \\
\text { Mean Age } \\
\text { (1st Assess.) }\end{array}$ \\
\hline \multirow{3}{*}{25} & \multirow{3}{*}{ (Stattin et al., 2011) } & \multirow{3}{*}{ Sweden } & (Kerr et al., 2010) & Disclosure & \multirow{3}{*}{ n.a. } & AP & --- & --- \\
\hline & & & --- & \multirow{2}{*}{$\begin{array}{l}\text { Parental } \\
\text { Knowledge }\end{array}$} & & MA & 2 & 13.89 \\
\hline & & & (Kerr et al., 2010) & & & $\mathrm{AP}$ & --- & --- \\
\hline 26 & $\begin{array}{l}\text { (Stavrinides, Georgiou, \& } \\
\text { Demetriou, 2010) }\end{array}$ & Cyprus & 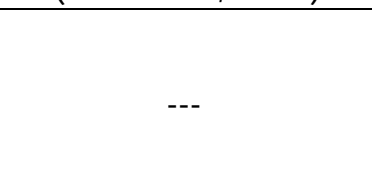 & $\begin{array}{l}\text { Disclosure } \\
\text { Parental Control } \\
\text { Parental } \\
\text { Solicitation }\end{array}$ & n.a. & $M A$ & 0.25 & 15.07 \\
\hline 27 & $\begin{array}{c}\text { (Stavrinides, Nikiforou, \& } \\
\text { Georgiou, 2015) }\end{array}$ & Cyprus & --- & $\begin{array}{l}\text { Disclosure } \\
\text { Parental Control } \\
\text { Parental } \\
\text { Solicitation }\end{array}$ & n.a. & MA & 0.5 & 13.5 \\
\hline 28 & $\begin{array}{l}\text { (Strandberg, Bodin, \& } \\
\text { Romelsjö, 2014) }\end{array}$ & Sweden & --- & Parental Control & $\begin{array}{l}\text { Male } \\
\text { Female }\end{array}$ & AP & 1.5 & 14 \\
\hline 29 & (Tilton-Weaver, 2014) & Sweden & --- & $\begin{array}{l}\text { Disclosure } \\
\text { Parental Control } \\
\text { Parental } \\
\text { Solicitation } \\
\text { Secrecy }\end{array}$ & n.a. & AP & 2 & 13.72 \\
\hline 30 & (Tilton-Weaver et al., & Sweden & (Kerr et al., 2010) & $\begin{array}{l}\text { Disclosure } \\
\text { Parental Control }\end{array}$ & n.a. & AP & --- & --- \\
\hline & & & -- & Secrecy & & & 3 & 15.04 \\
\hline 31 & $\begin{array}{c}\text { (Van der Giessen et al., } \\
2014)^{*}\end{array}$ & $\begin{array}{l}\text { The Netherlands - } \\
\text { RADAR }\end{array}$ & (Keijsers et al., 2012) & $\begin{array}{l}\text { Disclosure } \\
\text { Parental Control }\end{array}$ & n.a. & MA & 5 & 16.05 \\
\hline 32 & $\begin{array}{c}\text { (van der Zwaluw et al., } \\
2010) * *\end{array}$ & --- & --- & --- & --- & --- & --- & --- \\
\hline 33 & $\begin{array}{c}\text { (Willoughby \& Hamza, } \\
\text { 2011) }\end{array}$ & Canada (Ontario) & $\begin{array}{l}\text { (Hamza \& Willoughby, } \\
\text { 2011) }\end{array}$ & $\begin{array}{l}\text { Disclosure } \\
\text { Parental Control }\end{array}$ & $\begin{array}{l}\text { Male } \\
\text { Female }\end{array}$ & AP & --- & -- \\
\hline
\end{tabular}


Note: * reference used in analyses when datasets overlap (data about time-span covered by the assessment and Adolescents mean age are reported only for the study used as reference).** Data not available from the paper and upon the request from the authors;

${ }^{1} \mathrm{PA}=P$ arents to Adolescent; $\mathrm{MA}=\mathrm{M}$ other to Adolescent; $\mathrm{FA}=$ Father to Adolescent; $\mathrm{AM}=\mathrm{Adolescent}$ to $\mathrm{M}$ other; $\mathrm{AF}=\mathrm{Adolescent}$ to Father; $\mathrm{AP}=\mathrm{Adolescent}$ to Parents. In the Measure column, When Disclosure is reported without the variable Secrecy in correspondence of a specific study, the original scale of Stattin and Kerr (2000) with 5 items was used. When both Disclosure and Secrecy are listed, two of the items of the original scale were attributed to Secrecy and three to Disclosure. 
Records identified through database searching $(\mathrm{n}=1651)$
Additional records identified through screening latest issues

$$
(\mathrm{n}=0)
$$

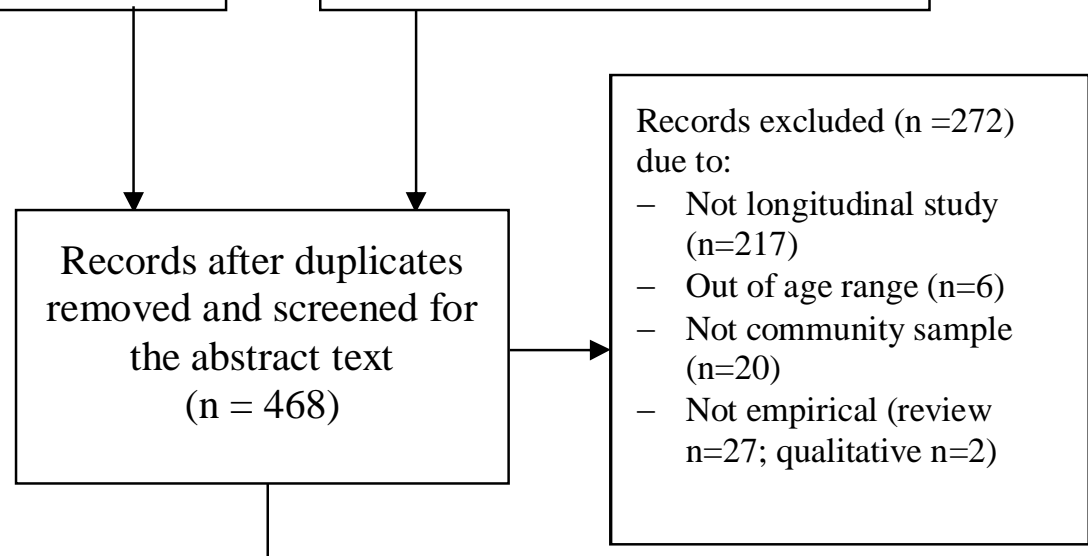

Full-text articles excluded $(n=163)$, due to:

- Not items proposed by Stattin and Kerr $(\mathrm{n}=135)$

Full-text articles assessed for eligibility

- Not correct sample $(n=1)$

- Non-longitudinal studies $(n=20)$

- Target variables data collection not longitudinal $(\mathrm{n}=7)$

Two studies were excluded from the meta-analysis: no complete data were present on the paper and we did not have answer by emailing the Authors

Studies included in quantitative synthesis (meta-analysis)

$$
(\mathrm{n}=31)
$$


Figure 2. Effect size distribution of parental control with duration of study ( $1=$ less than 2 years; $2=$ two or more years) as a moderator

\begin{tabular}{ll} 
Group by & Study name \\
\hline Duration of study &
\end{tabular}

1.00

1.00

1.00

1.00

1.00

1.00

1.00

1.00

2.00

2.00

2.00

2.00

2.00

2.00

2.00

2.00

2.00

2.00

2.00

Overall
Kiesner et al (2009)_canad

Kiesner et al (2009)_italy

Merrilees et al. (2011)

Munoz et al. (2011)

Stavrinides et al (2015)

Stavrinides et al. (2010)

Strandberg et al. (2014)

Creemers et al (2015)

Glatz, Stattin \& Kerr (2011)

Hamza \& Willoughby (2011)

Janssen et al. (2014)

Keijsers \& Poulin (2013)

Keijsers (2012)

Keijsers et al. (2009)

Kerr et al (2010)

Tilton-Weaver (2014)

Van der Giessen et al. (2014)
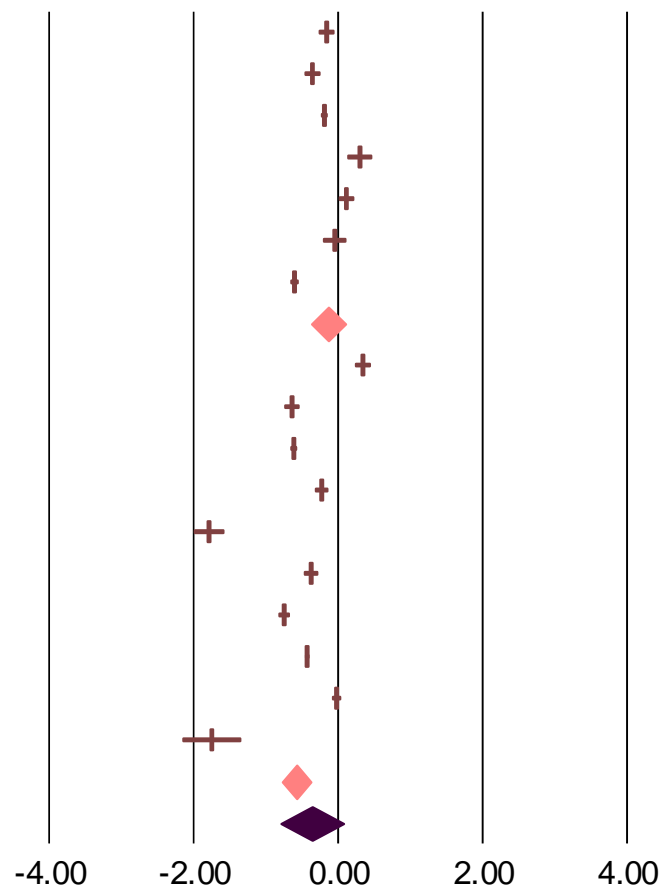

Decreasing
2.00

4.00

\section{Random effect model}

Figure 2. Effect size distribution of parental control with duration of study (1=less than 2 years; $2=$ two or more years) as a moderator 


\section{Study name}

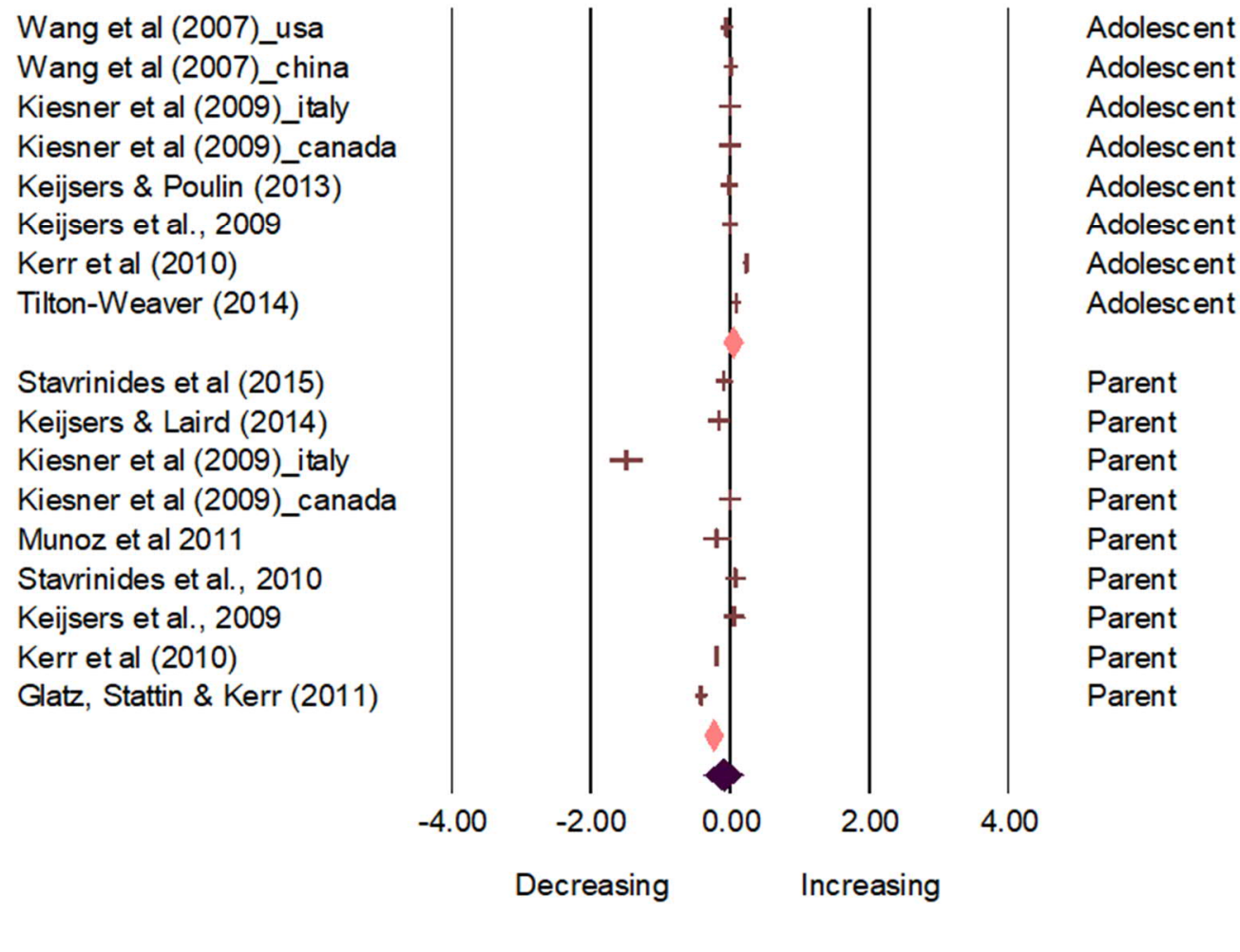

Figure 3. Effect size distribution of parental solicitation with informants (adolescent vs parent) as a moderator. 


\section{Study name}

Keijsers \& Poulin (2013)

Salafia, Gindoli \& Groundy (2009)

Hawk et al. (2013)

Reynolds et al. (2011)

Kerr et al (2010)

Keijsers (2010)

Stattin et al. (2011)

Garthe et al (2014)

Giannotta, Ortega, \& Ciairano (2011)

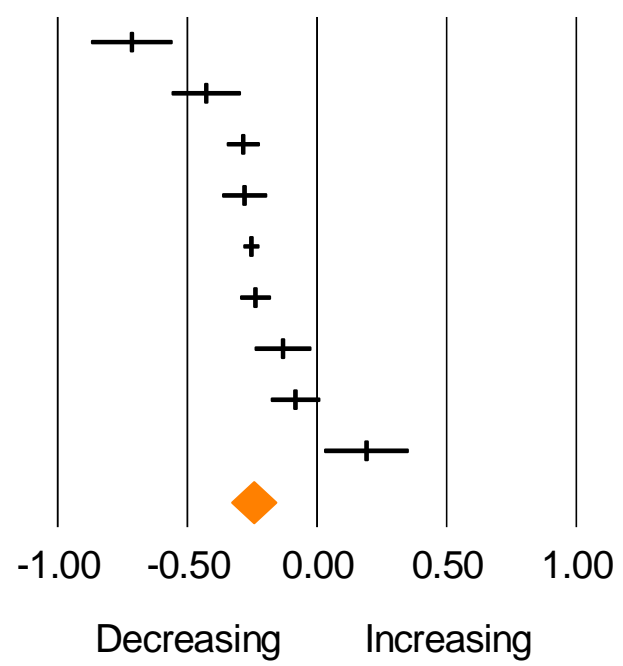

Random effect model

Figure 4. Effect size distribution of parental knowledge 


\section{Study name}

Cheung et al (2013)_china Cheung et al (2013)_usa Garthe et al (2014)

Hamza C.A., Willoughby, T. 2011

Keijsers \& Laird (2014)

Keijsers \& Poulin (2013)

Keijsers et al., 2009

Kerr et al (2010)

Kiesner et al (2009)_can

Kiesner et al (2009)_italy

Salafia, Gindoli \& Groundy (2009)

Stavrinides et al (2015)

Stavrinides et al., 2010

Tilton-Weaver (2014)

Van der Giessen et al. (2014)

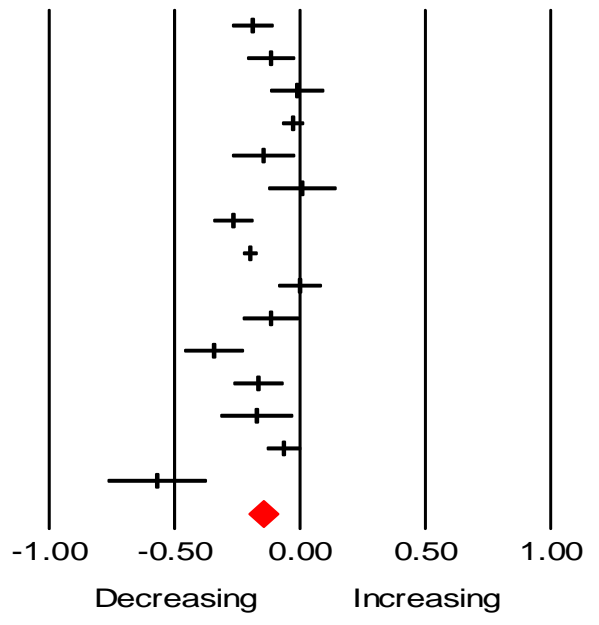

Random effect model

Figure 5. Effect size distribution of adolescent disclosure 


\section{Study name}

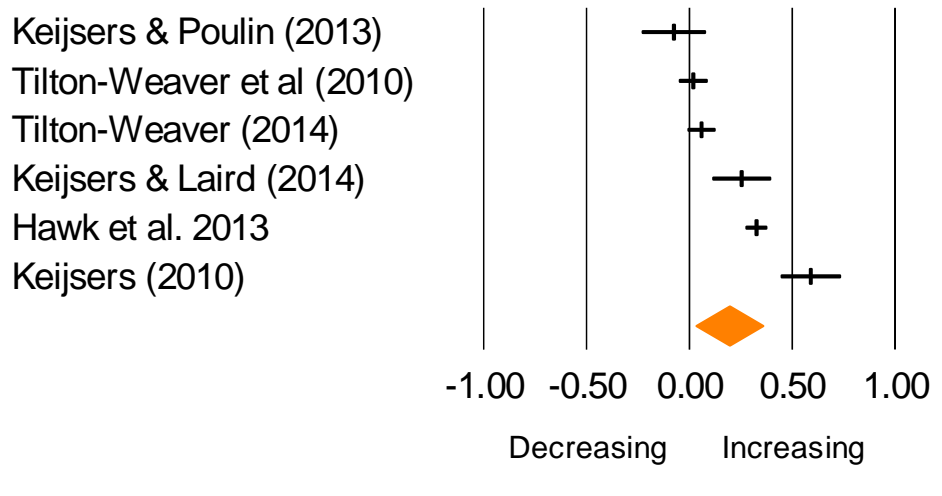

Random effect model

Figure 6. Effect size distribution of adolescent secrecy 